\title{
Transport System and Climate Change Risks: Potential Adaptation Constraints and Opportunities in Ghana
}

\author{
Gerald Atampugre ${ }^{a}$, Martin Larbi ${ }^{b}$, Thomas Kolawole Ojo ${ }^{c}$ \& Gengyuan Liu ${ }^{d}$ \\ ${ }^{a}$ Department of Geography, Environment, and Population, University of Adelaide, Adelaide, SA, Australia, 5005. \\ ${ }^{b}$ School of Architecture and Built Environment, University of Adelaide, Adelaide, SA, Australia, 5005. \\ [1] ${ }^{c}$ Department of Geography and Regional Planning, University of Cape Coast, Cape Coast, Central Region, Ghana. \\ ${ }^{d}$ School of Environment, Beijing Normal University, PR China. \\ [1] Corresponding Author
}

\begin{abstract}
This review explored the potential climate risks for transportation and probable institutional constraints and opportunities for adaptation in Ghana. Using documentary research and on the foundation of the Transport Sensitivity Framework and the Action Theory of Adaptation, policy and programme documents on transportation and climate change in Ghana were analyzed. The results indicate that potential consequences will be in two-fold; risks related to direct impacts on infrastructure and operations and risks associated with climate-induced socio-economic changes. There are three critical constraining issues; lack of data-driven information on potential climate impacts on transport systems; misalignment (or overlap) of institutional roles; and the lack of a framework for mainstreaming climate change documentation in transport plans. An opportunity for transport adaptation is that existing institutional and policy arrangements are amenable to review and reforms in the short-term. Thus, in amending these policies there must be concerted efforts towards the long-term integration of potential climate impacts and adaptation options into transport planning, designing, construction, maintenance, and operations.
\end{abstract}

KEYWORDS: Transport System; Climate Change; Adaptation; Ghana

\subsection{INTRODUCTION}

Mobility is not only an inextricable human right, but also fundamental to human survival. Consequently, any disruption in the various components of the transport system (i.e. infrastructure, operations, and demand) has the potential of derailing the system's performance and enfeebling its contribution to the broader development of a society. Globally, climate change has emerged as a major threat to transporta tion (Savonis et al., 2014; Nursey-Bray et al., 2012 Jaroszweski et al., 2010; Schmidt \& Meyer, 2009). Some of the expected far-reaching implications of climate change for transportation include, but not limited to; direct impacts on transport infrastructure and operations, network and mobility effects, accident frequency and severity, changes in passenger travel patterns (travel behavior), and other indirect socio-economic impacts (See Koetse \& Rietveld, 2012; Jaroszweski et al., 2010; Koetse \& Rietveld, 2009; Transportation Research Board (TRB) 2008; Koetse \& Rietveld, 2007; Mills \& Andrey, 2002). These impacts are particularly grave in developing countries and densely populated locations where one single climate event may trigger a chain of reactions with consequences for the wider society. Vulnerability assessment in the transport sector is rapidly evolving, with more progress achieved in addressing the short-run demand side (Koetse \& Rietveld, 2009). Nevertheless, further studies on the assessment of response strategies are necessary due to the increasing trends of climate change impacts on human society, and the ecosystem in general (Savonis et al., 2014; Koetse \& Rietveld, 2012; Schmidt \& Meyer, 2009).

In the last decade, there has been an improved understanding of climate change risks and vulnerabilities of the transportation sector (Becker, 2012; Koetse \& Rietveld, 2009; Nursey-Bray et al., 2012). However, a significant gap the full integration of climate impacts in transportation planning, design, and operations remains unresolved (Savonis et al., 2014; Chinowsky \& Arndt, 2012; Koetse \& Rietveld, 2012; Schmidt \& Meyer, 2009). Moreover, although it is widely acknowledged that transport systems perform worse under bad climate and weather conditions, studies focusing on 
potential climate responses for the sector remain limited (TRB, 2008; Climate Change Science Program (CCSP), 2008; Ribeiro et al., 2007). Savonis et al. (2014:p27) highlight this point by arguing that “...adaptation planning and implementation lag except where disasters have struck". Consequently, more research and action is needed to better understand and adopt a range of potential response strategies in anticipation of potential climate change impacts on transport systems (Koetse \& Rietveld, 2012). Globally, few developed countries like Australia, Canada, The Netherlands, Denmark, Japan, New Zealand, and the USA have adopted several approaches seeking to incorporate climate change documentation in the planning of (transport) infrastructure. In contrast, not much research and action has been done in developing countries where climate change has been projected to be disproportionately severer (Cervigni et al., 2015; Jones et al., 2013; Jeon et al., 2006).

The transport sector in Ghana is expanding side by side with its growing economy in line with global economy, trade and world population (Moomen, 2012; Chen, 2010). The sector is critically important in Ghana's development efforts and mobility prospects. Projected trends in climate variables and extremes are likely to introduce several risks and uncertainties over the future of the sector's contribution to the country's wider socio-economic agenda (Nelson et al., 2010). However, a closer look at existing policy documents and institutional initiatives suggest that not much primacy has been given to transport adaptation to climate change risks (See Mensah et al., 2016; Nelson et al., 2010).

A review of the National Climate Change Policy (NCCP) (2013), National Climate Change Adaptation Strategy (NCCAS) (2012) and the National Climate Change Master Plan (NCCMP) (2015-2020) indicates that all three documents are less elaborate on climate change impacts on and adaptation of transport infrastructure and operations. In fact, the prominence of transportation in these documents is mainly because of its contribution to the climate change problem (emission and mitigation). Again, the National Transport Policy (NTP) (2008), the National Integrated Transport Plan (NITP) (2010), and the transport Sector Medium-Term Development Plan (SMTDP) (2014) also give an indication that climate risks for transportation is not a priority (See Mensah et al., 2016; Moomen, 2012). Thus, this primer explores the potential climate risks for Ghana's transport system and the institutional constraints and opportunities for adaptation. This review is particularly important because of the imminent implications for safety, operations, and maintenance of the transport system. Although transportation planning and management must be informed by data-driven information on potential impacts and the probability of the risks, the non-existence of empirical data should not be considered a barrier to adaptation.

\subsection{RESEARCH METHOD}

The review uses documentary research (DR) for the study. DR is the sourcing and review of documents that contain information on a subject of interest (Bailey 1994). It has also been described as the analysis of "any written material other than a record that was not prepared specifically in response to some requests from the investigator" (Guba \& Lincoln (1981: p.228). Based on the above interpretations, the sourcing and review of policy documents in this study fits appropriately under the domain of DR. Arguably, documents are important source of information and may be used in several ways in social sciences research (Atkinson \& Coffey (1997). Denscombe (1998) similarly emphasises the attractiveness government publications and official statistics to social research. According to Ahmed (2010), DR is just as good as and sometimes even more cost effective than in-depth interviews, social survey or participant observations. The argument here is that, using DR aids the situation of the issues of inquiry within the theoretical frame of reference. This is important because it improves the understanding of results of the inquiry. In this study, DR was used to enable a reflexive approach towards highlighting the underpinnings of the review objective. Using this method of research broadens the foundations on which the key points of discussions are based. The paper used DR to gather secondary data and information on transportation system planning (infrastructure, operations and demand) vis-à-vis climate adaptation constraints and opportunities in Ghana.

\subsection{CONCEPTUAL AND THEORETICAL PERSPECTIVES}

This section discusses the conceptual and theoretical basis for this primer, highlighting how an in-depth understanding of the climate-related sensitivities of transport systems and the requisite adaptation pathways could enable resilient transportation industry under future climate change. The following subsections discuss the Transport sensitivity framework and the Action Theory of Adaptation. 


\subsection{Transport system sensitivity to climate change: a conceptual framework}

Sensitivity, as a concept, varies across authors and disciplines. In the frame of this paper, the definition by the IPCC is applied. According to the IPCC (2007) sensitivity is the degree to which a system is affected adversely or beneficially by climate related stimuli. In line with this definition, Birkmann et al. (2013) argue that the sensitivity of a system (socialecological) is its predisposition to risks. Accordingly, sensitivity is used in this paper to highlight the susceptibility of Ghana's expanding transport system to climate stimuli. The transport system can be viewed from a supply and demand perspective, where infrastructural provision and operations constitute supply while the need and use of transport services constitute the demand side. According to Koetse and Rietveld (2009) and also in TRB (2008), though anthropogenic climate change has implications for both sides, the focus of research and policy actions predominantly address the short-run demand side of the system. Mills and Andrey (2002) proposed a transport sensitivity framework that seeks to delineate the potential impacts of anthropogenic climate change on the various components of a transportation system (Figure 4).
Anthropogenic climate change potentially alters the frequency, duration, and severity of climate elements and extremes. These changes have both direct implications for planning and design, construction, maintenance, and indirect impacts on demand (e.g. location, timing, mode, sector, etc.). Following this observation, Mills and Andrey (2002: p2) highlight that "...costs and benefits, measured in terms of safety, mobility, economic efficiency, and externalities, will accrue as the operation of transportation facilities and services meets these demands and adjusts to weather and climate hazards". Transport infrastructure in most instances is designed and built for typical climate or weather patterns. However, with anthropogenic climate change influencing the variability of weather and extremes, its critical to reassess how climate/weather patterns are incorporated in infrastructural designs. The relationship between damaged infrastructure and transport operation is direct. For instance, when floods and storms wash away roads, road transport operations on that route is also altered. Altering operations means demand (e.g. location, timing and mode) for services through that route must necessarily change. Subsequent sections use this conceptualization of transport-climate interaction to assess potential impacts

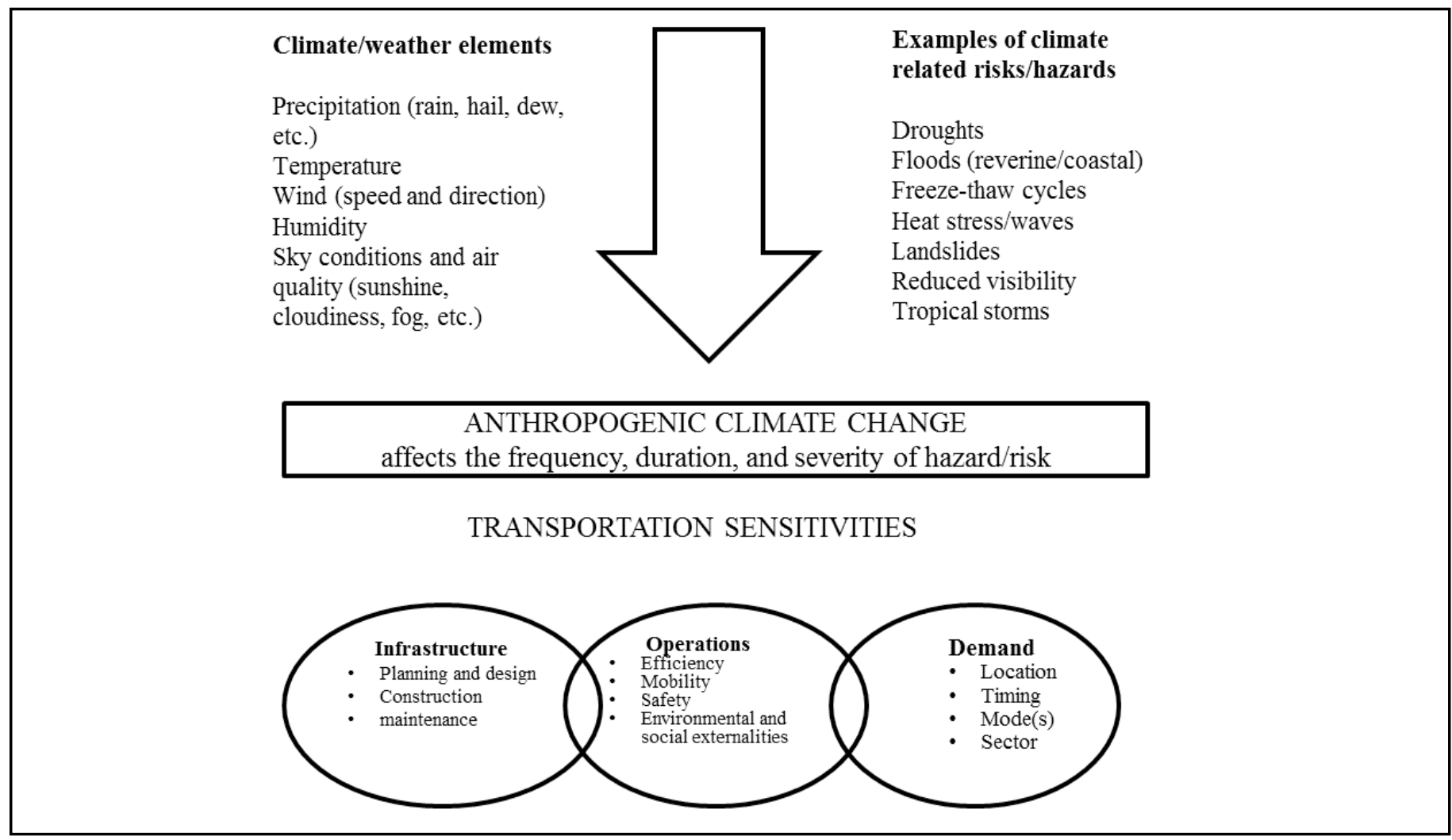


of future climate change projections on Ghana's transport system.

\subsection{The Action Theory of Adaptation}

Adaptation, according to the IPCC, refers to "...initiatives and measures to reduce the vulnerability of natural and human systems to actual or expected climate change effects" (IPCC, 2014). Adaptation to imminent impacts of climate change is increasingly gaining prominence among scientist and policy makers (Thornton et al., 2014; IPCC, 2014: 2012; Eisenack \& Stecker, 2012; McLaughlin, 2011; Adger et al., 2009). Most scholarly literature attribute this to the increasing confidence in climate change projections and the fact that it has become clearer that mitigation alone cannot forestall additional impacts for decades to come (Thornton et al., 2014; IPCC, 2012; National Research Council (NRC) 2010).

The Action theory of adaptation (See Eisenack \& Stecker, 2012) is applied in this primer from a sectoral adaptation context. According to the UNFCCC (2006), sectoral adaptation refers to “...the adjustments by individual sectors of a socio-ecological system (SES) in response to climate change risks". Echoing this point, Eisenack \& Stecker (2012) note that these adaptive adjustments require actors, intentions, and means to achieve the desired outcomes (Figure 5). They argue that the various theoretical contributions to 'adaptation' provide a good basis for understanding the concept and introduces some critical variables for adaptation theory (e.g. McLaughlin, 2011; Adger et al., 2009; O'Brien et al., 2007; Smit \& Wandel, 2006; Brooks, 2003; Smit \& Pilifosova,
2001; Smith \& Lenhart, 1996). These contributions however, they opined, are less comprehensive in drawing conclusions for adaptation governance. Thus, Eisenack \& Stecker (2012) proposed the 'action theory of adaptation' as a contribution towards refining the roles of the various components of the system that adapts to stimulus. The basic tenet of this framework is that adaptation is a 'collective action'. Framing adaptation as collective actions, refining the purpose of such actions and how they tend to link up in means-ends chains is crucial to the adaptation process (Eisenack \& Stecker, 2012). It is important to mention that exposure units, receptors of adaptation actions, and operators of adaptation may take up different roles in the system.

According to Eisenack and Stecker (2012: p4) stimulus refers to "...statistical changes in meteorological variables associated with climate change" (See Figure 3). In the context of this analysis, we operationalize stimulus as changing variability in climate/weather elements (e.g. rainfall and temperature) and extreme events (Figure 4). The basis for this conceptualization can be traced to Thornton et al. (2014) argument that the concentration of most climate change studies on changes in the mean climate/weather values alone could seriously lead to underestimation of the full impacts on socioecological systems (also see Katz \& Brown, 1992). Besides, it is imperative to recognize that climate change cannot be observed in the everyday life but rather inferred from the spatially and temporally narrow clustering of changing weather patterns or extreme events like droughts, floods, and storms (Christmann et al., 2014). It is important to high-

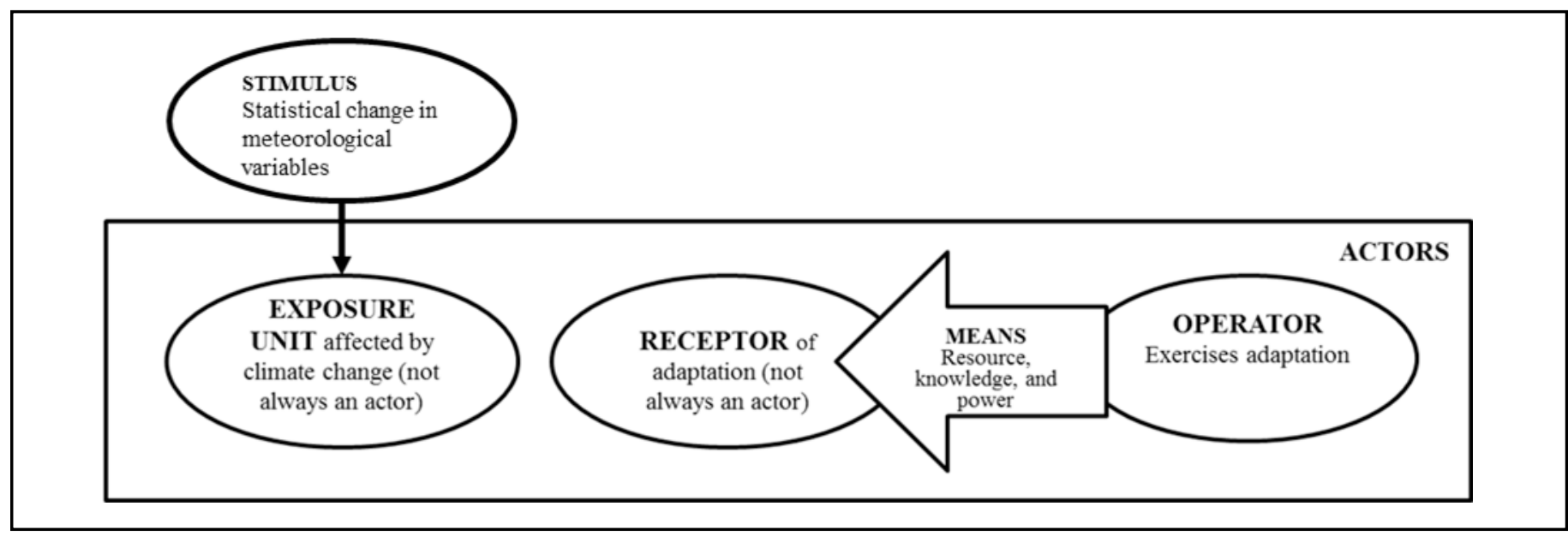

Figure 2: Schematic representation of the Action Theory of Adaptation.

Note: Exposure unit, receptor and operator can be actors. They are not necessarily identical.

Source: Eisenack \& Stecker (2012) 
light that these climate or weather extremes become relevant for adaptation only when they interact with the context of the exposed unit (See Figure 4). That is, to be sensitive to climate-related stimuli, the unit must necessarily be exposed.

The exposure unit in this regard refers to the transportation system expected to be affected by climate or weather-related extremes. The term encompasses transport infrastructure (e.g. planning, designing, construction, and maintenance), transport operations (e.g. efficiency, mobility, and safety, environmental and social externalities) and transport demand (e.g. location, timing, and mode) that may be considered for adaptation. For instance, the deterioration/degradation of road infrastructure (exposure unit) due to severe floods (stimulus) represents an impact. The same could be said for delay in flights due to poor atmospheric visibility or effects of frequent rain storms on mobility of goods. These could be regarded as qualitative conceptualizations of climate impacts on transportation systems. a relevant extension of this paper could be to actually quantify the actual transport system damages due to climate stimuli. This is in line with Eisenack and Stecker (2012: p5) delineation of 'actors'. In the context of this manuscript, the transport sector (infrastructure and operations) is the target of the intended adaptation by the "operator".

The operator in this context refers to the collective actors that exercise the intended transport adaptation. These actors are both private and public bodies that run the system. The purpose of their operations is to reduce the susceptibility of the transport system to climate stimuli. The actors include, but not limited to, Government (e.g. Ministries, Agencies and Departments), Private Transport stakeholders (e.g. GPRTU), and Donor partners (e.g. World Bank, European Union etc.). These institutions are required to act collectively through prerequisite 'means' in response to climate impacts on transportation. It is important to highlight that, without dimensioning the role of the other actors, government is the most important stakeholder in the system due to its role in terms of policy and infrastructural investments.

To implement transport adaptation policies or strategies, actors require some resources, referred to as 'means'. These may include availability of datadriven information, enhanced knowledge, financial, and the general institutional capacity. Eisenack and Stecker (2012: p6) differentiate three notions of 'means', available means, employed means, and necessary means. They referred to disposable resources of the operator us 'available means' whilst the 'employed means' indicates the part of the resources actually used for a specific adaptation. They argue that the effectiveness of an adaptation requires the use of the 'necessary means', which might be available or not. For instance, unused institutional capacity which could have otherwise been used for more alternative or complementary adaptive actions represents a 'necessary means'.

In Eisenack and Stecker (2012: p6) conceptualization, four types of adaptation constraints are emphasized; missing operator, missing means, unemployed means, and complex actor relations (Box 1). Missing operator refers to actors' ignorance of climate impacts, implying no adaptation. Missing means refers to the unavailability of necessary means even with the existence of an operator. a situation where there is an operator with necessary means but are not sufficiently used for adaptation is referred to as 'unemployed means'. a complex network of exposure units, receptors and operators could hinder the adaptation decision making process (complex actor relations).

\subsection{OVERVIEW OF CLIMATE CHANGE PROJECTIONS IN GHANA}

By virtue of Ghana's location in the tropics, the country is vulnerable to climate change risks (MEST 2010). There is consensus that climate will be more variable in decades to come, with implications for the frequency and severity of climate/weather extremes. According to World Bank (2010), annual rainfall over Ghana is highly variable on inter-annual and inter-decadal time scales making it difficult to identify long-term trends. However, their precipitation forecast for the country shows a cyclical pattern over the period of 2010-2050, with high precipitation levels followed by a drought every decade. The World Bank (2010) also highlights warming over Ghana, with a temperature increase of up to $2.2^{\circ} \mathrm{C}-2.4^{\circ} \mathrm{C}$ by 2050 . It is also explicit in the report that the average temperature in Ghana during the period $2010-2050$ will range between $34^{\circ} \mathrm{C}$ and $41^{\circ} \mathrm{C}$, with significant temperature variability of between $4.3^{\circ} \mathrm{C}$ and $5.7^{\circ} \mathrm{C}$.

In Ghana's third communication to the UNFCCC (See GEPA 2015), rainfall across the country is 


\section{Table 1: Types of constraints based on the Action Theory of Adaptation}

\section{No. Adaptation Constraints Description}

1 Missing operators

When there is no operator due to complete actor ignorance of impacts, there is no adaptation. In this case, not even the necessary means for adaptation are known. Due to a vague problem awareness, adaptation is hindered on the base of missing means in terms of individual knowledge about impacts or due to conditions that prohibit problem awareness (e.g. high information costs, social habits and normative standards). This hinders adaptation although action is not constrained by limited available means.

2 Missing means

3 Unemployed means

\begin{abstract}
The necessary means are not available although there is an operator. Although there is no lack of perceived problem urgency (e.g. by even the exposure units themselves), limited institutional capacity and/or budget constraints hinder appropriate adaptation. This is crucial, in particular, for many developing countries that are disproportionally exposed to climate change and already have limited capacities to cope with other severe stresses. Another variant are missing responsibilities, when motivated operators do not have the legal power to act.
\end{abstract}

\begin{abstract}
Means are not sufficiently employed although there is an operator to whom the necessary means are available. When an adaptation has positive externalities for other actors, the operator may choose to under-adapt when s/he considers that other exposure units that benefit from the adaptation are not contributing their share to the 'means'. By symmetry, it might also be the case that the operator over-adapts when the action has negative effects on other exposure units. There are also perverse moral hazard situations where means are employed to increase the consequences of impacts. In many cases settlements are (re)built in high risk areas (e.g. due to flooding). Investors (exposure units) push planning decisions towards their own favour, since they expect compensation from the public (as operator) in the case of a disaster. In sum, this type of barrier refers to misaligned incentives in the economic analysis.
\end{abstract}

It might also be that the network of exposure units, operators and receptors is too complex to come to decisions. Since climate change has very diverse effects which are relevant for many exposure units in different ways, there are likely to be many decision conflicts. These might be amplified by established institutional arrangements that are not tailored to the new type of adaptation challenge. Reckien et al. (2008) shows how different actor types can be entangled for adaptation in the transport sector. For new problems it is not always ex ante clear which the relevant actors are. Economically speaking, all these problems raise the transaction costs of information search, monitoring and contract enforcement. This inhibits available means and can increase the necessary means.

Source: Adapted from Eisenach and Stecker (2012: pp11-12)

projected to decrease by $2.9 \%$ in 2040 , followed by a slight increase of $1.1 \%$ by 2060 , and later decrease by $1.7 \%$ in 2080 . According to the GEPA (2015) "...this observation is a reflection of the uncertainty associated with rainfall in Ghana". Analyzing historical temperature data between 1981 and 2000, the GEPA (2015) observed a $2 \%$ change rate in minimum temperature for southern Ghana and $37 \%$ for northern (Guinea and Sudan Savanah zones). The GEPA (2015) predicts that the mean temperatures are likely to increase by $1.20 \mathrm{C}, 1.5^{\circ} \mathrm{C}$, and $1.8^{\circ} \mathrm{C}$ in 2021-2040, 2041-2060, and 2061-2080 respectively. The imminent implications of these projections are that climate and weather extreme events will be affected in terms of frequency, duration, severity, and intensity. This will in turn impact every sector of the Ghanaian economy.

\subsection{OVERVIEW OF TRANSPORT INSTITUTIONS AND POLICIES}

The transportation sector is identified as one of the key sectors for the acceleration of Ghana's socio-economic growth (African Watch Magazine, 2014; MoFEP, 2010). Although the transport sector accounts for a large portion of public investment, it also provides huge stimulus for socio-economic growth. In the last decade, transport sector's contribution to Gross Domestic Product (GDP) has been on the increase, with forecasts showing a further increase to 3,937 GHS Million by 2020 (TradingEconomics \& Ghana Statistical Service, 2017). Currently the transport sector contributes 3,873 GHS Million to GDP. The country's transport system is concentrated in the south where major urban cities (e.g. Accra, Tema, 
Kumasi, and Takoradi) and major economic activities are found (mining, cocoa production, timber production). Over the years, there have been consistent efforts by governments towards building "essential” transport infrastructure and services to, domestically, facilitate access to jobs, education, and health, while also promoting international trade (Ghana National Commission for UNESCO 2010). This undertaking underscores the notion that the availability of an efficient and continuously responsive transport system is crucial to Ghana's socio-economic stability. This section provides an overview of transport sector institutions and policies in Ghana.

In Ghana's Fourth Republic (1993 to date), transport related institutions have metamorphosed on many occasions, depending on which government (political party) was in power. Despite the existence of the National Transport Policy (NTP), there have always been the issue of (re)creation and (re)alignment of institutions based on the perspective of the ruling government. However, all transport sector institutions are defined by Ghana's institutional framework, which is built around four key functions: Policy formulation; regulation; asset management; and service provision. According to Ministry of Transport (MoT) (2008), these functions establish two separate relational arrangements in the sector: First, the institutional framework defines the relationship between policy formulation, assets management, and management and maintenance of services. Secondly, it defines the relationship between policy formulation, market regulation, and transport Service provision.

Currently, there are four "realigned" government ministries with oversight responsibilities for the various modes of transport in Ghana. These are the MoT, Ministry of Roads and Highways (MoRH), Ministry of Railway Development (MoRD), and

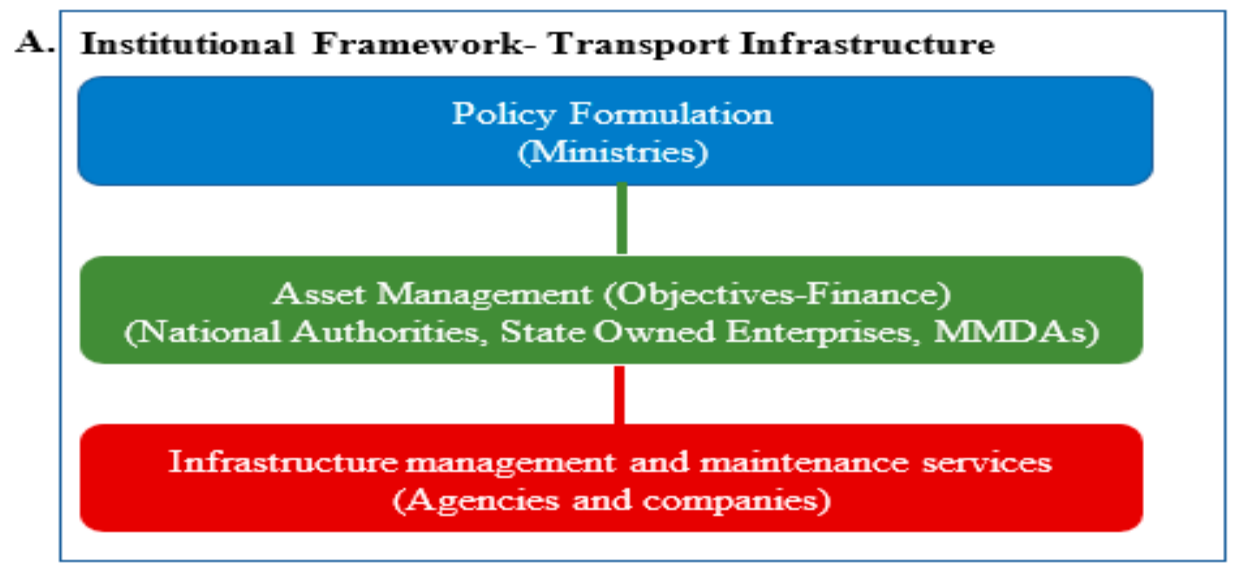

B. Institutional Framework- Transport Services
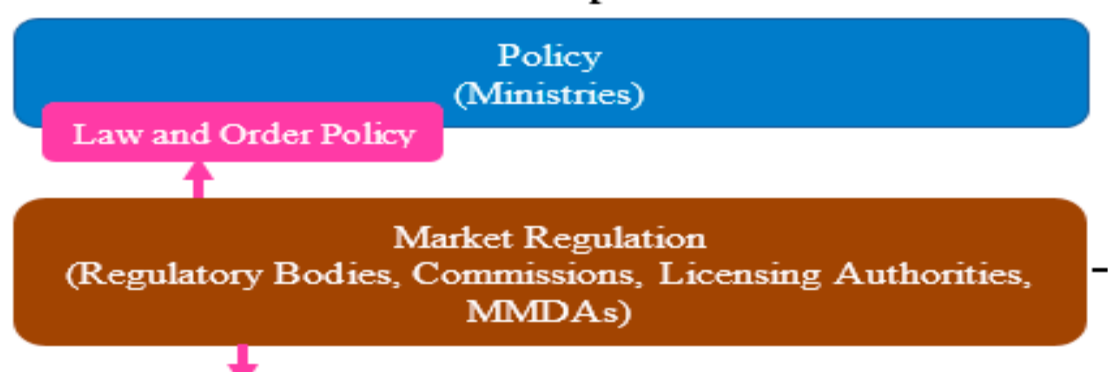

Law Enforcement

(Law enforcement agencies)

License + fees

Transport Service Providers + Drivers

(Public and Private Limited Companies + people)

Figure 3: Institutional framework for transport infrastructure and services

Source: Modified from National Transport Policy (2008). 
Ministry of Aviation (MoAv). These four sub-sector ministries (first level institutions) are responsible for policy formulation, coordination, and oversight and enabling (See Figure 3ga). Under these ministries are various National Authorities, Departments, Agencies, and State Owned Enterprises or Public-Private enterprises (e.g. Metro Mass Transit Ltd, Driver and Vehicle Licensing Authority, Ghana Highway Authority (GHA)). These second level affiliates are charged with the responsibility of asset management. The third level institutions in the "supply" side of the transportation system are the agencies and companies responsible for infrastructure management and maintenance services (e.g. Ghana Airport Company Ltd, Ghana Port and Harbor Authority). The supply side of the transport sector is largely related to transport policies on infrastructure provision and management. Progress has been made in the water transport sector in terms of institutional reforms. This has led to separation of roles: the policy (i.e. for MoT), regulatory (i.e. for GMA), asset management (i.e. for GHAPOHA) and service functions of the subsector. The implementation of the Ports Master Plan will go a long way to improve marine transport.

The supply of transportation is contingent on the demand for it. The demand side of the institutional framework is made up of policy makers (government ministries), planners, regulators, producers, and service providers from key sectors of the economy (Figure 3b). According to the MoFEP and Egis BCEOM International (2010), key sectors creating the demand for transport sector include but not limited to:

- Energy: National petroleum Authority, Energy Commission, Ghana National Petroleum Company, Electricity Generating Company, Bulk Oil and Storage Company, Oil Companies (Exploitation) and Oil Marketing Companies (Distribution)

- Lands and Mineral Resources: Minerals Commission, Forestry Commission, Mining Companies, Logging and timber manufacturing companies

- Trade and Industry: Free Zone Board, Manufacturers, Traders and Retailers Cocoa board, cocoa marketing companies, growers, processors

- Foods and Agriculture: Growers, distributers, wholesalers and markets
The above list, though not exhaustive, gives an indication of the diversity of transport needs and the magnitude of the responsibility of meeting Ghana's economy-wide transport demand.

The Table 2 gives an overview of transport related institutions, summarizing their oversight responsibilities and policy objectives. The MoT is responsible for policy development, coordination, and oversight of railway, roads, aviation, and inland and maritime transport sub-sectors. In collaboration with the MoRH, NTP and SMTDP were developed. The MoRH is responsible for policy development, coordination and oversight of road infrastructure. It also oversees the activities of the Department of Urban Roads (DUR), Department of Feeder Roads (DFR), the Ghana Road Fund (GRF) and GHA. The Ministry of Aviation (MoAv) and Ministry of Railway Development (MoRD) are relatively new after being decoupled from the MoT in 2017. Aviation under the MoT had two key institutions, the Ghana Civil Aviation Authority (GCAA) responsible for regulating the aviation sub-sector and the Ghana Airports Company Limited (GACL) responsible for the management of airport infrastructure. These two institutions are now under the responsibility of the Aviation Ministry. The management of the airports infrastructure by GACL, has been hampered by uncertainties about its ownership of assets (including those to be transferred from GCAA) and the long-term tenure of airport lands.

The MoRD on the other hand is now responsible for policy development, coordination, and oversight for railway, including the activities of the Ghana Railway Development Authority (GRDA) which is responsible for regulating rail operators and managing the rail infrastructure assets and the Ghana Railway Company Limited (GRCL) responsible for providing passenger and freight rail services. GRDA was created to plan and manage Ghana's railway infrastructure assets but lacks the capacity and resources to fully implement its responsibilities (MoT, 2014). With this plethora of institutions comes the critical need for collaboration and coordination. As part of the implementation of the NITP, there has been an increase in the number of formal mechanisms for collaboration and coordination between and among Ministries. However, without the clear mandate for coordination and integration between the modes, priorities will always tend to be determined by the formalized institution mandates. 
Table 2: Summary of transport related institutions, responsibilities and policy

\begin{tabular}{|c|c|c|}
\hline Institution & Oversight responsibility & Policy objectives \\
\hline $\begin{array}{l}\text { Ministry } \\
\text { of Transport }\end{array}$ & $\begin{array}{l}\text { Roads, aviation, railway, } \\
\text { and inland and maritime, }\end{array}$ & $\begin{array}{l}\text { - To ensure safe, reliable, and accessible transport system with the } \\
\text { provision, expansion and maintenance of transport infrastructure and } \\
\text { services in Ghana. } \\
\text { To develop a multi-disciplinary human-resource base and the use of new } \\
\text { technology to strengthen institutional capacity for implementation of } \\
\text { programmes and projects. } \\
\text { To review, develop and strengthen the appropriate legal, environmental } \\
\text { and regulatory framework that will ensure an efficient and accessible } \\
\text { transport system. } \\
\text { To promote a sustainable legal and regulatory framework that will } \\
\text { promote Public Private Partnership (PPP) in the provision of transport } \\
\text { infrastructure and services. }\end{array}$ \\
\hline
\end{tabular}

\begin{tabular}{|c|c|c|}
\hline $\begin{array}{l}\text { Ministry } \\
\text { of Roads and } \\
\text { Highways }\end{array}$ & $\begin{array}{l}\text { Road infrastructure: } \\
\text { Urban, rural, and highways }\end{array}$ & $\begin{array}{l}\text { - } \quad \text { Create and sustain an accessible, effective and efficient transport network } \\
\text { - Integrate land use, transport planning, development planning and service } \\
\text { provision } \\
\text { - } \quad \text { Create a vibrant investment and performance-based management } \\
\text { environment that maximize benefits for public and private sector investors } \\
\text { - Develop and implement comprehensive and integrated Policy, } \\
\text { Governance and Institutional Frameworks } \\
\text { - Develop a multi-disciplinary human resource base to facilitate the } \\
\text { implementation of our programmes and projects }\end{array}$ \\
\hline
\end{tabular}

\begin{tabular}{|c|c|c|}
\hline $\begin{array}{l}\text { *Ministry } \\
\text { of Aviation }\end{array}$ & $\begin{array}{l}\text { Domestic and international } \\
\text { air transport }\end{array}$ & $\begin{array}{l}\text { - } \quad \text { planning, developing, managing and maintaining all airports and } \\
\text { aerodromes in Ghana } \\
\text { - } \quad \text { Airspace management and Safety Regulations } \\
\text { - } \quad \text { Provision of Air Navigation Services (Air Space Management) within the } \\
\text { - } \quad \text { Promoting PPP for the Development of Civil Air Transport Industry } \\
\text { - } \quad \text { Research and training of skilled personnel }\end{array}$ \\
\hline $\begin{array}{l}{ }^{*} \text { Ministry } \\
\text { of Railway } \\
\text { Development }\end{array}$ & $\begin{array}{l}\text { Development of Railway } \\
\text { system }\end{array}$ & $\begin{array}{l}\text { - To plan, develop and improve railway Assets } \\
\text { - To promote the development and management of suburban railway } \\
\text { through Public-Private Partnership } \\
\text { - To ensure effective regulation and monitoring of activities of licensees, } \\
\text { concessionaires and operators in railway sub-sector } \\
\text { initiate, conduct, and promote studies necessary for the growth and } \\
\text { development of railways including the development and implementation } \\
\text { of railway master plan }\end{array}$ \\
\hline
\end{tabular}

\subsection{TRANSPORTATION AND CLIMATE ADAPTATION IN GHANA: STIMULATING THE DISCUSSION}

Ghana's transport system is a critical component in the country's supply chains and communications. Transportation, in general, is a very complex system with responsibilities distributed across many different stakeholders, requiring many costly and longterm investments in infrastructure and operations. Hence, transport infrastructure and operations affected by processes of climate change (e.g. increasing temperatures, severe variability in rainfall, heat waves, storms, rising sea levels, etc.) produce significant adverse repercussions for mobility and the wider socio-economic growth. In this section, we discuss the potential impacts of projected climate change on Ghana's transportation, highlighting institutional constraints to and opportunities for transport adaptation.

\subsection{Potential impacts}

The planning, designing, construction of transport infrastructure is executed with considerations for local weather and environmental conditions (Sa- 
vonis et al., 2014; Mills and Andrey, 2002). However, with current projections of climate change, the implications are that historical climate data and some assumptions about imminent climate and weather conditions may be wrong which may precipitate the deterioration or failure of transport network (UNDP-Africa adaptation programme, 2011; TRB, 2008; Mills and Andrey, 2002). Previous studies have established that all transport modes will be affected by climate change (See Savonis et al., 2014; CCSP, 2008; TRB, 2008). Considering existing challenges in Ghana's transport sector, the indications are that the potential consequences could be in two-fold; risks related to physical impacts on infrastructure and operations and risks associated with the resultant climate-induced socio-economic changes.

The direct impacts of climate change include, but not limited to, increased deterioration and deformation of transport infrastructure and more frequent interruptions of transport operations, resulting in mobility and economic inefficiencies in the system (Table 3). In the road transport subsector, expected frequent and severer floods and storms could lead to frequent inundation (erosion and deterioration) of road infrastructure that have implications on passenger and freight safety. Anticipated increases in storm events could result in frequent landslides along road networks in hilly areas, leading to disruptions in road transport. The disruption in road transport operations is consequential to system efficiency in the sense that it could lead to increased cost in terms of time lost, increased transportation cost, and increases in maintenance cost (Boateng, 2012; UNDP-Africa adaptation programme, 2011; World Bank, 2010).

The deformation of rail track due to severe temperature anomalies have safety, mobility, and efficiency implications. Truck buckling and rolling stock overheating (or failure) result in speed restrictions and higher needs for cooling. This may lead to increased rail construction and maintenance cost. Coupled with existing challenges in the rail sub-sector, the Ghana Railway Master Plan requires a review that will give due considerations to these potential medium- to long-term impacts. Projected increases in temperatures may also cause heat buckling of runways and aircraft lift, which may result in payload restrictions, cancellations and the general disruption of services at airports (Moomen, 2012). Frequent air traffic disruptions due to severe climate/weather events could also be expected. This may have implications for departure and arrival rates (Moomen,
2012; UNDP-Africa adaptation programme, 2011; Koetse \& Rietveld, 2009).

In the coastal zone, where large urban cities and significant transport infrastructure are found, projected Sea Level Rise (SLR) could have dire consequences for the countries development (Table 3). These coastal cities are already experiencing frequent storm surges, flooding and high tide wave events (Komey, 2015; Moomen, 2012). a good example is the Keta sea erosion problem which has seen huge investments from government and its development partners. With projected SLR due to anthropogenic climate change, port facilities will be affected by increased storm surges leading to periodic inundation and interruption of shipping services. Again, breakwaters protecting ports could be rendered less efficient, requiring raising and/or strengthening. SLR may result in larger tidal prisms and foundation scouring (or silting), all of which could hamper operations at the ports. Destruction of port equipment, navigational aids, and reduced ship access to docks are consequences that could be associated with projected SLR.

Ghana could also experience economic losses due to low water levels for inland water transport. Changes in rainfall and temperature influences water levels in lakes and rivers (Koetse \& Rietveld, 2009; Jonkeren et al., 2007), implying consequences for inland passenger and freight mobility. Already fluctuating water levels have been identified by authorities as a major challenge to transportation on the Volta Lake. According to the NITP, low water conditions in the Lake (due to reduced rains and high temperatures) prevent longitudinal movement of freight and passengers. On the other hand, the high water levels due to heavy rainstorms makes it near impossible to use landing facilities around Lake. All these operational disruptions could potentially intensify with projected climate changes (Jonkeren et al., 2007).

Apart from the direct physical impacts, it is also imperative to note that climate change-induced socio-economic changes could also considerably affect Ghana's transport system. Demand for transport infrastructure and services is contingent on economy, trade, and population. As a demand-driven sector, climate-related changes in the production of a commodity and its spatial distribution, population distribution, tourism patterns, trade, and consumption patterns could also affect the functioning of the transportation system (Moomen, 2012; Koetse \& Rietveld, 2009). For instance, changes in the location of food 
Table 3: Potential climate risks for transport infrastructure and operations in Ghana

\begin{tabular}{|c|c|c|}
\hline Climate Factor & Potential impacts on infrastructure & Potential impacts on operations \\
\hline $\begin{array}{l}\text { Increased mean } \\
\text { temperatures/Heat waves/ } \\
\text { more hot days and more cold } \\
\text { nights, droughts, "hamattan" }\end{array}$ & $\begin{array}{ll}\text { - } & \text { Asphalt deterioration } \\
\text { - } & \text { Rutting, potholes, waterlogging of roads } \\
& \text { phermal expansion of bridge joints, } \\
\text { - } & \text { Deformation of rail tracks (buckling) } \\
\text { Deformation of runways }\end{array}$ & $\begin{array}{l}\text { - Safety issues: passenger and freight e.g. } \\
\text { derailing of trains, road accidents, false } \\
\text { landing due to poor visibility, etc. } \\
\text { Mobility inefficiencies: cost in terms } \\
\text { of time lost, e.g. due cancelations and } \\
\text { diversions } \\
\text { Economic inefficiencies: Increased } \\
\text { transportation cost and increased } \\
\text { maintenance cost }\end{array}$ \\
\hline $\begin{array}{l}\text { Frequent and severer Floods, } \\
\text { frequent and intensive storms }\end{array}$ & $\begin{array}{l}\text { Weathering/erosion of transport } \\
\text { infrastructure } \\
\text { More frequent flooding of transport } \\
\text { infrastructure in vulnerable areas (e.g. } \\
\text { coastal and low laying roads, tunnels, } \\
\text { rails, etc.) } \\
\text { Greater probability of transport } \\
\text { infrastructure failure (e.g. port facilities, } \\
\text { roads signs, etc.) }\end{array}$ & $\begin{array}{l}\text { - Safety issues: accidents e.g. collision on } \\
\text { roads, derailing of trains } \\
\text { Mobility inefficiencies: increased } \\
\text { weather related delays and disruptions } \\
\text { in operations, particularly road and air } \\
\text { transports } \\
\text { - Economic inefficiencies: increased } \\
\text { transportation cost, increased } \\
\text { maintenance cost }\end{array}$ \\
\hline $\begin{array}{l}\text { Sea level rise and storm } \\
\text { surges }\end{array}$ & $\begin{array}{l}\text { Increased corrosion rate and } \\
\text { degradation of port facilities, coastal } \\
\text { roads and rails. } \\
\text { Erosion or accretion of beaches } \\
\text { protecting port structures, roads, and } \\
\text { rails. } \\
\text { - Flooding and direct erosion of coastal } \\
\text { transport infrastructure }\end{array}$ & $\begin{array}{l}\text { - More frequent interruptions in port } \\
\text { activities and coastal road and rail } \\
\text { transport. } \\
\text { - Increased maintenance costs at ports } \\
\text { - Effects on offshore loading and } \\
\text { unloading operations. } \\
\text { - Regularity of ports, downtime and } \\
\text { requirements for more storage capacity } \\
\text { at container terminals for use in times of } \\
\text { closure. }\end{array}$ \\
\hline
\end{tabular}

production hubs may require changes in the transport system to facilitate movement of food to "critical points". In Ghana, agriculture is a major contributor to GDP and it is considered the most vulnerable sector as it is mainly rain-fed. As a result, shifts in production patterns due to irregular rains, droughts, climate-induced diseases and pests, etc. may have substantial implications for trade and freight transportation patterns and demand. The emphasis here is that a better understanding of climate impacts in other sectors may permit a better understanding of latent derivative climate consequences on transport systems (See TRB, 2008).

\subsection{Transport adaptation constraints and opportunities}

In 2013, Chinowsky et al. found that Africa will potentially face a $\$ 183.6$ billion USD liability to repair and maintain roads damaged by precipitation and temperature dynamics directly related to climate change by 2100 (Chinowsky et al., 2013). Cervigni et al. (2015) have also argued that “...modifying existing investment plans to explicitly capture the risks of large climate swings can cut in half or more the cost that would accrue by building infrastructure on the basis of past climate". These and other studies in the USA and Europe emphasize the urgent need for the integration of potential climate risks into long term planning of transportation infrastructure and operations (See Savonis et al., 2014; Tayler \& Philip, 2011; Koetse \& Rietveld, 2009; Schmidt \& Meyer, 2009; TRB, 2008; CCSP, 2008). In the context of Ghana, not much has been done in terms of potential adaptation for transport systems. In fact the only document that explicitly deals with transport and climate change is a qualitative UNDP-AAP scoping and impact assessment report in 2011 (See UNDP-AAP, 2011). However, a review of separate national policy documents on transportation and climate change gives an overview of the possible constraining factors and opportunities for transport adaptation to climate 
projections. By constraining factors to transport adaptation, this paper makes reference to circumstances or conditions that may not enhance adaptive actions or provide 'means' for improving adaptive capacity of transport system in Ghana. The adaptation barriers as proposed under the "action Theory of Adaptation" and sensitivity areas as identified in the "Transport Sensitivity Framework" are used as a guide to illustrate the constraints to transport adaptation in Ghana (Figure 4).

Ghana is gradually shifting the emphasis from reactive disaster risk management to medium-and long-term disaster resilience. These efforts resonate with transport sector development. However, there are varied institutional barriers to building a resilient transport system in the phase of changing climate and extremes. One of the major constraining factors is the complex actor (stakeholder) relations which makes it difficult for prompt and effective decision making (See Figure 4). Transportation, anywhere in the world has a complex web of stakeholders who may be exposure units, receptors of adaptation, or collective actors who exercise adaptation. In the Ghana context, this complexity manifests in the plethora of government and non-governmental institutions (possible operators of adaptation), and the ever increasing transport operation entities (possible exposure units, receptors, and operators). There is some level of diversity in what connects each of these institutions to the climate change problem and consequently, may lead to decisional conflicts as argued by (Eisenack \& Stecker 2012). As shown in this paper, the overlaps in mandates and reactive actions among transport sector institutions, makes it unclear who the adaptation 'operators' are. With limited coordination and collaboration between and among in-

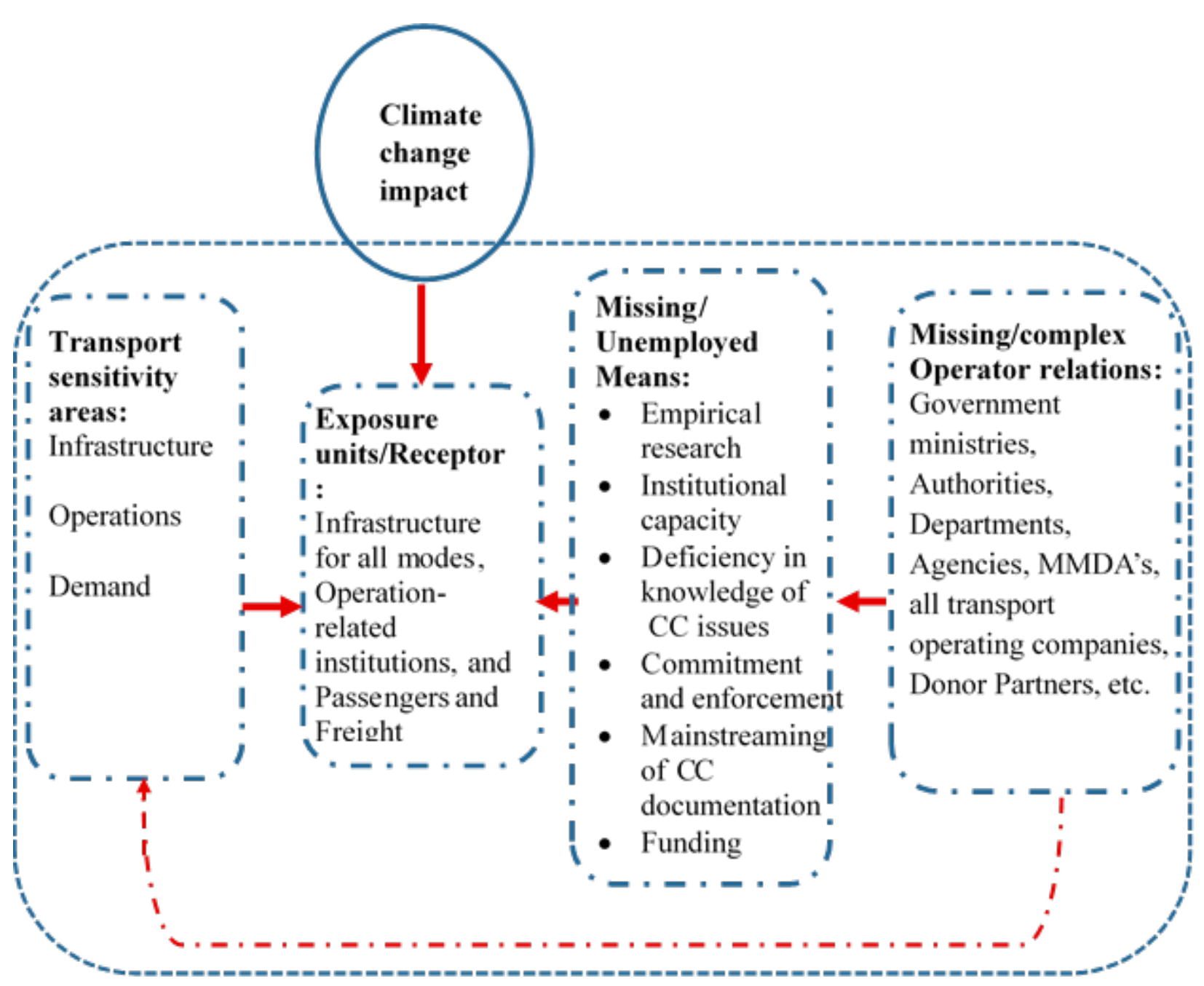


tuitions, 'necessary means' are expected to increase due to increases in transaction cost (for empirical research, implementation, monitoring, and enforcement of actions). Inevitably, the 'available means' at the disposal of institutions (operators of adaptation) will reduce. It is, therefore, imperative to emphasize that any misalignment of actor roles could present barriers to effective adaptation, generating adverse implications for the system (maladaptation).

Another key challenge will be the fact that relevant institutions that are supposed to exercise adaptation are limited in their knowledge (or have a vague awareness) of the expected impacts from anthropogenic-induced climate change (captured as missing operator in Figure 4). Reviewed documents emphasized human and institutional capacity as a major challenge to climate adaptation. Relevant institutions, therefore, will require appropriately qualified personnel to fulfil the separate responsibilities of climate change documentation and integration into medium- to long-term transport development. There is also the urgent need for institutional capacity building, especially the creation and strengthening of environmental units in the various institutions. The review also established that although policies and plans attempted to mainstream climate change adaptation, the technical specification, standards, and design guides that tend to incorporate climate change variables are nonexistent. It becomes imperative in this regard to equip relevant institutions with operational and well-resourced research and development systems.

A cautious attempt at integrating the policies captured in the below table (Table 4) presents a good starting point for the mainstreaming of climate

Table 4: Policies relevant to transport system adaptation

\begin{tabular}{|c|c|c|}
\hline Policy & $\begin{array}{l}\text { Key Climate } \\
\text { change Priorities }\end{array}$ & Key Transport priorities \\
\hline $\begin{array}{l}\text { National Transport Policy } \\
\text { (2008) }\end{array}$ & $\begin{array}{l}\text { Transport } \\
\text { Emission } \\
\text { reduction }\end{array}$ & $\begin{array}{l}\text { - Outlines the need for transport infrastructure and services in the } \\
\text { context of sub-regional, national and local growth objectives. } \\
\text { Provide guidance on priorities for investment and reform that } \\
\text { enable and facilitate achievement of the strategic objectives for } \\
\text { transport within the policy framework } \\
\text { - Provide a long-term decision making platform for the effective } \\
\text { management and development of Transport infrastructure and } \\
\text { Services } \\
\text { Provide a platform for dialogue and guidance on the roles and } \\
\text { responsibilities of key Stakeholders }\end{array}$ \\
\hline $\begin{array}{l}\text { National Integrated } \\
\text { Transport Plan (2010) }\end{array}$ & $\begin{array}{l}\text { Transport } \\
\text { Emission } \\
\text { reduction }\end{array}$ & $\begin{array}{l}\text { - Integration of modes } \\
\text { - Integration of transport and land-use } \\
\text { - Integration with the whole government policies / strategic sector } \\
\text { plans (creating an integrated policy environment) }\end{array}$ \\
\hline $\begin{array}{l}\text { Transport Sector Medium- } \\
\text { Term Development Plan for } \\
\text { Implementation } 2014-2017\end{array}$ & $\begin{array}{l}\text { Transport } \\
\text { Emission } \\
\text { reduction }\end{array}$ & $\begin{array}{l}\text { - Create a sustainable, accessible, affordable, reliable, effective, } \\
\text { efficient, safe and secure transport system that meets user needs. } \\
\text { Develop and integrate land use, transport planning, development } \\
\text { planning and service provision. Create appropriate environment for } \\
\text { private sector participation in the delivery of transport infrastructure. } \\
\text { - Develop and implement a comprehensive and integrated Policy, } \\
\text { Governance and Institutional Framework. } \\
\text { - } \quad \text { Ensure Sustainable Development in the Transport sector. } \\
\text { Develop adequate Human Resources and apply new Technology. }\end{array}$ \\
\hline
\end{tabular}

\begin{tabular}{lll}
\hline *National Climate Change & Adaptation & General infrastructure adaptation \\
Adaptation Strategy (2012) & & \\
\hline *National Climate Change & Impacts, & Transport Emission reduction \\
Policy (2013) & $\begin{array}{l}\text { Mitigation, } \\
\text { adaptation }\end{array}$ &
\end{tabular}

\section{*National Climate} Change Master Plan Action Programmes for Implementation: 2015-2020
Adaptation programmes General infrastructure adaptation and transport emission reduction for priority areas 
change issues into transport development agenda. As it clearly shows, transportation related policies and plans do not emphasize adaptation and pays little attention to transport emission reduction. It is, however, important to note that some of these policies and plans are for the short- to medium-term, and thus are amenable to reviews and reforms. It is therefore crucial that these reviews and reforms commit to considering climate change related information generated from empirical research. For instance, the NCCMP and the SMTDP are due for reviews in 2020 and 2017 respectively. It is this paper's expectation that these reviews will thoroughly consider adaptation of transport infrastructure and operations to identified imminent climate impacts in the mediumto long-term.

The current national transport policy (NTP) presents some opportunities for transport adaptation. The NTP was formulated integrating three frameworks: Policy framework, governance framework, and institutional framework. Each of these frameworks presents some guidelines for the resolution of identified adaptation constraints and the mainstreaming of potential climate change impacts into transportation planning. For instance, the institutional framework resolves the issue of mandate overlaps by distinguishing between transport infrastructure-related institutional arrangements and transport operations-related institutions. Within each of these arrangements, institutional responsibilities are clearly delineated. Policy makers and practitioners in the transport sector could draw on these frameworks especial for the review and subsequent reform of the National Integrated Transport Plan.

This primer also established that the issue of unreliable and unsustainable funding featured prominently in most of the policy documents, which could serve as a barrier to transport adaptation (See Mensah et al 2016; Asante et al. 2015). Mainstreaming climate change documentation into national transport policies and programmes requires that stakeholders (especially government) interrogate the various financial options available for the extra demand (See Asante et al. 2015; Nelson et al. 2010). Policy formulation and implementation in Ghana has largely been sponsored by donor partners which are not reliable source for medium- to long-term actions (See Asante et al. 2015). This is particularly the case for Official Development Assistance (ODAs) which are mostly in grants and the financial support from multilateral and bilateral institutions. To guarantee that expected climate change documentation remains an integral part of transport sector development in Ghana, Foreign Direct Investments (FDI) and local private sector investments must be encouraged. One way of encouraging this public private partnership with foreign and local investors is that government could be committed to passing laws and by-laws to enforce the use of technical specifications, standards, and design guidelines in the supply of transport infrastructure and services.

Mainstreaming transport-relevant climate change information into national and regional level transportation plans (programmes or projects) will require a framework that comprehensively integrates the issues at all levels of the decision making process or at each stage of the transport planning cycle. In their guidebook titled "Integrating Climate Change and Disaster Risk Reduction into National Development, Policies and Planning in Ghana”, Nelson et al. (2010) emphasized that mainstreaming climate change goes beyond simply adding on climate change themes in national development frameworks. According them it encompasses processes that assess the consequences of any planned action (e.g. policies, plans, programmes, and projects) in any sector and at all levels. Mensah et al. (2016) argue that it must also include the assessment of the mandate of the institutions (e.g. MoT, MoRH, MoAv, and MoRD) and their relationships with other relevant intuitions (e.g. MESTI, MoLGRD, MoLNR, MoC, MoEP, MoFA). On the bases of these arguments and that made by Becker (2012), we propose that effective mainstreaming and the long-term transport adaptation, integration of reliable climate change documentation should be done at all institutional levels, especially those captured in the national transport development master plan. We emphasize that integration must cut across transport policies, planning, designing, construction, maintenance, operations, and funding mechanisms.

\subsection{CONCLUSIONS AND POLICY IMPLICATIONS}

Arguably, the effects of anthropogenic climate change on Ghana's transportation network may or may not be substantial. However, considering the uncertainties surrounding expected impacts of climate change, business as usual cannot be a prudent alternative. Fortunately, the service lifespan of most transport infrastructure is sufficiently short (less than 25years) 
(Mills and Andrey 2002). This affords stakeholders (e.g. government) the opportunity for cost-effective replacements using apposite climate-resilient plans and designs for transport systems..

The existing policies and strategies present a strong foundation for transport adaptation. However, the misalignment of actor roles (missing operators and complex actor relations) and the unavailability of some 'means' (missing necessary means) introduces some obstacles and uncertainties for transport sector adaptation to climate change projections in Ghana. There is need for efforts at increasing human and institutional capacity for the extra demand of adaptation. We emphasize that the nonexistence of reliable empirical data or information should not be considered a barrier to adaptation. This because in the phase of uncertain changes in climate and extremes flexible/adaptive strategies could be adopted. However, more efforts should be directed at empirical research on: potential climate impacts on transportation and its probabilities; adaptive transport planning options; and how these adaptation options can be mainstreamed into national transportation policies and practices. We argue for increased commitment towards integrating considerations of potential climate impacts and adaptation options into transport planning, designing, construction, maintenance, and operations.

\section{REFERENCES}

Adger, W. N., Dessai, S., Goulden, M., Hulme, M., Lorenzoni, I., Nelson, D. R. \& Wreford, A. 2009. Are there social limits to adaptation to climate change? Climatic change, 93(3), 335-354.

Africawatch Magazine 2014. Transporting Ghana into the future: a special report. October 2014 edition, Available at: http:// www.mot.gov.gh/files/resources/Special_Report_on_Ghanas_ Transport_Sector.pdf

Asante, F. A., Bawakyillenuo, S., Bird, N., Trujillo, N.C., Addoquaye Tagoe, C., and Ashiabi, N., 2015. Climate change finance in Ghana, ODI Report, Available at: http://www.odi.org/sites/ odi.org.uk/files/odi-assets/publications-opinion-files/9684.pdf accessed 4th October, 2015.

Becker, P. 2012. The importance of integrating multiple administrative levels in capacity assessment for disaster risk reduction and climate change adaptation. Disaster Prevention and Management: An International Journal, 21(2), 226-233.

Birkmann J., Cardona, O. D., Carren o, M. L., Barbat, A. H., Pelling, M., Schneiderbauer, S., Kienberger, S., Keiler, M., Alexander, D., Zeil, P. \& Welle, T. 2013. Framing vulnerability, risk and societal responses: the MOVE framework. Natural Hazards, 67, 193-211
Boateng, I. 2012. An assessment of the physical impacts of sea-level rise and coastal adaptation: a case study of the eastern coast of Ghana. Climatic Change, 114(2), 273-293.

Brooks, N. 2003. Vulnerability, risk and adaptation: a conceptual framework. Tyndall Centre for Climate Change Research Working Paper, 38, 1-16.

Climate Change Science Program (CCSP) 2008. Effects of Climate Change on Energy Production and Use in the United States-Synthesis and Assessment Product 4.5, US Climate Change Program, Washington, DC

Cervigni, R., Liden, R., Neumann, J. E., \& Strzepek, K. M. 2015. Enhancing the Climate Resilience of Africa's Infrastructure: Power and Water Sectors. Africa Development Forum. Washington,DC: https://openknowledge.worldbank.org/handle/10986/21875 accessed $3^{\text {rd }}$ August, 2017.

Chen, G. 2010. Road traffic safety in African countries-status, trend, contributing factors, countermeasures and challenges. International journal of injury control and safety promotion, 17(4), 247-255.

Chinowsky, P., Schweikert, A., Strzepek, N., Manahan, K., Strzepek, K. \& Schlosser A. C. 2013. Climate change Adaptation advantage for African Road Infrastructure. Climatic Change, 117: 345-361.

Chinowsky, P. \& Arndt, C. 2012. Climate change and roads: a dynamic stressor-response model. Review of Development Economics, 16(3), pp233-262

Christmann, G. B., Balgar, K., \& Mahlkow, N. 2014. Local constructions of vulnerability and resilience in the context of climate change. a comparison of Lübeck and Rostock. Social Sciences, 3(1), 142-159.

Eisenack, K. \& Stecker, R. 2012. a framework for analyzing climate change adaptations as actions. Mitigation and Adaptation Strategies for Global Change, 17(3), 243-260.

Ghana National Commission for UNESCO 2010. Transport: Bedrock for Economic Development. In: Ghana UNESCO Magazine: Information Magazine Number 2, Accra, pp 193 - 198.

Ghana Environmental Protection Agency (GEAP) 2015. Ghana's Third National Communication to the UNFCCC-2015. Climate Change Report on Ghana, Available at http://unfccc.int/ resource/docs/natc/ghanc3.pdf accessed 24 ${ }^{\text {th }}$ April, 2015.

Ghana Environmental Protection Agency (GEAP) 2011. Ghana's Second National Communication to the UNFCCC-2011. Climate Change Report on Ghana. Available at http://unfccc. int/resource/docs/natc/ghanc3.pdf accessed 24 ${ }^{\text {th }}$ April, 2015.

Ghana Environmental Protection Agency (GEPA) 2001. Initial National Communication to the United Nations Framework Convention on Climate Change. Available at: http://unfccc.int/ resource/docs/natc/guinc1.pdf accessed 24 ${ }^{\text {th }}$ April, 2015.

Intergovernmental Panel on Climate Change (IPCC) 2014. Summary for policy makers. In: Field, C. B., V. R. Barros, D. J. Dokken, K. J. Mach, M. D. Mastrandrea, T. E. Bilir, M. Chatterjee, K. L. Ebi, Y. O. Estrada, R. C. Genova, B. Girma, E. S. Kissel, A. N. Levy, S. MacCracken, P. R. Mastrandrea, \& L. L. White (Eds.). Climate Change 2014: Impacts, Adaptation, and Vulnerability. Part A: Global and Sectoral Aspects- Contribution of 
Working Group II to the Fifth Assessment Report of the Intergovernmental Panel on Climate Change. Cambridge University Press, Cambridge, United Kingdom and New York, 1-32.

IPCC 2012. Managing the Risks of Extreme Events and Disasters to Advance Climate Change Adaptation. In: Field, C.B., V. Barros, T.F. Stocker, D. Qin, D.J. Dokken, K.L. Ebi, M.D. Mastrandrea, K.J. Mach, G.-K. Plattner, S.K. Allen, M. Tignor, and P.M. Midgley (Eds.). a Special Report of Working Groups I and II of the Intergovernmental Panel on Climate Change. Cambridge University Press, Cambridge, UK, and New York.

IPCC 2012: Summary for Policymakers. In: Managing the Risks of Extreme Events and Disasters to Advance Climate Change Adaptation In: Field, C.B., V. Barros, T.F. Stocker, D. Qin, D.J. Dokken, K.L. Ebi, M.D. Mastrandrea, K.J. Mach, G.-K. Plattner, S.K. Allen, M. Tignor, and P.M. Midgley (Eds.). a Special Report of Working Groups I and II of the Intergovernmental Panel on Climate Change. Cambridge University Press, Cambridge, UK, and New York, NY, USA, pp. 3-21.

IPCC 2007. Climate Change 2007: Impacts, Adaptation and Vulnerability, in M. Parry, O. Canziani, J. Palutikof, P. van der Linden, C. Hanson (Eds), Contribution of Working Group II to the Fourth Assessment Report on Climate Change, Cambridge University Press, Cambridge.

Jaroszweski, D., Chapman, L., \& Petts, J. 2010. Assessing the potential impact of climate change on transportation: the need for an interdisciplinary approach. Journal of Transport Geography, 18(2), 331-335.

Jeon, C. M., Amekudzi, A. A. \& Vanegas, J. 2006. Transportation System Sustainability Issues in High-, Middle-, and LowIncome Economies: Case Studies from Georgia (U.S.) South Korea, Colombia, and Ghana, Journal of Urban Planning and Development, 132(3), 172-186.

Jones, S., Tefe, M., \& Appiah-Opoku, S. 2013. Proposed Framework for Sustainability Screening of Urban Transport Projects in Developing Countries: a Case Study of Accra, Ghana. Transportation Research Part A: Policy and Practice. 49: 21-34.

Jonkeren, O., Rietveld, P., \& van Ommeren, J. 2007. Climate change and inland waterway transport: welfare effects of low water levels on the river Rhine. Journal of Transport Economics and Policy, 387-411.

Katz, R. W., \& Brown, B. G. 1992. Extreme events in a changing climate: variability is more important than averages. Climatic change, 21(3), 289-302.

Koetse, M. J. \& Rietveld, P. 2012. Adaptation to Climate Change in the Transport Sector, Transport Reviews, 32:3, 267-286, DOI: 10.1080/01441647.2012.657716

Koetse, M. J., \& Rietveld, P. 2009. The impact of climate change and weather on transport: An overview of empirical findings. Transportation Research Part D: Transport and Environment, 14(3), 205-221.

Koetse, M. J. \& Rietveld, P. 2007. Climate Change, Adverse Weather Conditions, and Transport: a Literature Survey. The Netherlands, Amsterdam: VU University, Department of Spatial Economics.

Komey, A. N. K. 2015. Institutional Adaptation to Climate Change and Flooding in Accra, Ghana. a thesis presented to the faculty of the Voinovich School of Leadership \& Public Affairs, in partial fulfilment of the requirements for the degree MSc. Available at: https://etd.ohiolink.edu/!etd.send_file?accession =ohiou1438820921\&disposition=inline

McLaughlin, P. 2011. Climate change, adaptation, and vulnerability: Reconceptualising societal-environment interaction within a socially constructed adaptive landscape. Organization \& Environment, 24(3), 269-291.

Mensah, A., Anderson, K. \& Nelson, W. 2016. Review of Adaptation Related Policies in Ghana, DECCMA Working Paper, Deltas, Vulnerability and Climate Change: Migration and Adaptation, IDRC Project Number 107642. Available at: https:// www.researchgate.net/profile/Adelina_Mensah/publication/299562846_Review_of_Adaptation_Policies_in_Ghana/ links/56ff696008ae650a64f72e77.pdf.

Mills, B. \& Andrey, J. 2002. Climate change and transportation: potential interactions and impacts. In: The potential impacts of climate change on transportation, a summary and discussion papers of the Federal Research Partnership Workshop, 1-2 October 2002, Brookings Institute, Washington DC. 77-88. Available at: http://climate.dot.gov/documents/workshop1002/ mills.pdf accessed on $23^{\text {rd }}$ April, 2015.

Ministry of Finance and Economic Planning (MoFEP) \& Egis BCEOM International 2010. Integrated Transport Plan for Ghana (NITP) 2011-2015. Volume 1, Available at: https://s3.amazonaws.com/ndpcstatic/CACHES/PUBLICATIONS/2016/05/03/ITPGhana_Vol+01+Integrated+Transpor t+Plan+2011-2015.pdf. Accessed $4^{\text {th }}$ August, 2017.

Ministry of Finance and Economic Planning (MoFEP) 2010. Strategic Environmental Assessment of the Transport Integration Plan for Ghana. Environmental report No 246602/HWI/08/A. Available at: https://europa.eu/capacity4dev/public-environment-climate/documents/sea-transport-integration-plan-ghana-2010. Accessed $7^{\text {th }}$ May, 2016.

Ministry of Transport (MoT) 2014. Sector mediumterm development plan (SMTDP) 2014-2017. Available: https://s3.amazonaws.com/ndpcstatic/CACHES/PUBLICATIONS/2016/07/15/Ministry+of+Transport+SMT DP+2014-2017.pdf Accessed $7^{\text {th }}$ May, 2016.

Ministry of Transport (MoT) 2008. National Transport Policy (NTP). Available at: http://www.mrh.gov.gh/files/publications/National_Transport_Policy___December_2008.pdf. Accessed $7^{\text {th }}$ May, 2016.

Ministry of Roads and Highways (MoRH) 2015. Annual performance report-2015. Available at: http://www.mrh.gov.gh/ files/publications/2015_Annual_Performance_Report.pdf. Accessed $7^{\text {th }}$ May, 2016.

Ministry of Roads and Highways (MoRH) 2014. Annual performance report-2014. Available at: http://www.mrh.gov.gh/ files/publications/2014_Annual_Performance_Report.pdf. Accessed $7^{\text {th }}$ May, 2016.

Ministry of Environment, Science, Technology and Innovation (MESTI) 2015. National Climate Change Master Plan (NCCMP): Policy Action Programmes for Implementation (2015-2020). Accra. Available at: https://www.weadapt.org/ sites/weadapt.org/files/ghana_national_climate_change_master_plan_2015_2020.pdf. $23^{\text {rd }}$ May, 2017. 
Ministry of Environment, Science, Technology and Innovation (MESTI) 2013. Ghana National Climate Change Policy (NCCP). Accra, Available at: http://www.un-page.org/files/public/ghanaclimatechangepolicy.pdf

Ministry of Environment, Science, Technology and Innovation (MESTI) 2012. National Climate Change Adaptation Strategy (NCCAS). Produced under the CC DARE joint programme by UNEP and UNDP. Accra. Available at: https://s3.amazonaws. com/ndpc-static/CACHES/PUBLICATIONS/2016/04/16/ Ghana_national_climate_change_adaptation_strategy_nccas.pdf. Accessed $7^{\text {th }}$ May, 2016.

Moomen, A. 2012. Air transport in Ghana: some climatic constraints. Aviation, 16(3), 88-95.

Nation Research Council (NRC) 2010. Advancing the science of climate change. National Academy Press, Washington DC.

Nelson W., Bonsu, W. K., Naambuyi, D., Owusu-Amoah, K., Antwi, J., Agbey, S., Boegriba, A., Yaro, J. A., Bempah, J., Boadi, O. Azasoo, J., Benefoh, D. T. \& Kissiedu, R. 2010. Integrating Climate Change and Disaster Risk Reduction into National Development, Policies and Planning in Ghana, Ghana Environmental Protection Agency (GEPA), Accra. Available at: https:// www.undp-aap.org/sites/undpaap.org/files/Ghana_Guidebook\%20on\%20Integrating\%20CC\%20and\%20Disaster\%20 Risk\%20into\%20National\%20Dev\%20Policies\%20and\%20 Planning\%20in\%20Ghana_august\%202010.pdf

Nursey-Bray, M., Blackwell, B., Brooks, B., Campbell, M. L., Goldsworthy, L., Pateman H., Rodrigues, I., Roome, M., Wright, J. T., Francis, J. \& Hewitt, C. L. 2013. Vulnerabilities and adaptation of ports to climate change, Journal of Environmental Planning and Management, 56(7), 1021-1045.

Nyantakyi-Frimpong, H. \& Bezner K. R. 2015. The relative importance of climate change in the context of multiple stressors in semi-arid Ghana. Global Environmental Change, 32, 40-56.

O’Brien, K., Sygna, L., Leichenko, R., Adger, W. N., Barnett, J., Mitchell, T., Schipper, L., Tanner, T., Vogel, C. \& Mortreux, C. 2008. Disaster risk reduction, climate change adaptation and human security. Report prepared for the Royal Norwegian Ministry of Foreign Affairs by the Global Environmental Change and Human Security Project, GECHS Report No.3, Norway.

Tsamboulas, D. 2012. Impacts and adaptation requirements of road networks. a UNECE Conference proceedings. Available at: http://www.unece.org/fileadmin/DAM/trans/doc/2012/ wp5/07_Mr_Tsamboulas.pdf. $24^{\text {th }}$ October, 2018.

Owusu, K. \& Waylen, P. 2009.Trends in spatio-temporal variability in annual rainfall in Ghana (1951-2000). Weather, 64(5), 115-120.

Ribeiro, S., S. Kobayashi, M. Beuthe, J. Gasca, D. Greene, D. S. Lee, Y. Muromachi, P. J. Newton, S. Plotkin, D. Sperling, R. Wit, P. J. Zhou, 2007: Transport and its infrastructure. In Climate Change 2007: Mitigation. Contribution of Working Group III to the Fourth Assessment Report of the Intergovernmental Panel on Climate Change In: B. Metz, O.R. Davidson, P.R. Bosch, R. Dave, L.A. Meyer (Eds). Cambridge University Press, Cambridge, United Kingdom and New York, NY, USA.

Savonis, M. J., Potter, J. R., \& Snow, C. B. 2014. Continuing challenges in transportation adaptation. Current sustainable renewable energy reports, 1(1), 27-34.
Schmidt, N., \& Meyer, M. 2009. Incorporating climate change considerations into transportation planning. Transportation Research Record: Journal of the Transportation Research Board, (2119), 66-73.

Smit, B. \& Wandel, J. 2006. Adaptation, adaptive capacity and vulnerability. Global Environmental Change, 16(3), 282-292.

Smit, B. \& Pilifosova, O. 2001. Adaptation to climate change in the context of sustainable development and equity. In: J. J. McCarthy, Canziani, O. F., Leary, N. A., Dokken, D. J. \& White, K. S. (Eds.). Climate change 2001: impacts, adaptation and vulnerability. Cambridge University Press, Cambridge, 877-912.

Smith, J. B. \& Lenhart S. S. 1996. Climate change adaptation policy options. Climate Research. 6, 193-201.

Stanturf, J. A., Warren, M. L., Charnley, Jr. S., Polasky, S. C., Goodrick, S. L., Armah, F. \& Nyako, Y. A. 2011. Ghana Climate Change Vulnerability and Adaptation Assessment. US Agency for International Development, Washington. Available at http://www.encapafrica.org/documents/biofor/Climate $\% 20$ Change\%20Assessment_Ghana_\%20FINAL.pdf

Taylor M. A. P. \& Philip M. 2011. Adapting to climate changeimplications for transport infrastructure, transport systems and travel behaviour. a NCCARF position paper No. 2. Available at: https://www.nccarf.edu.au/sites/www.nccarf.edu. au.settlements-infrastructure/files/file/FINAL_VERSION_ NODE2_PP2_INFRASTRUCTURE.pdf

Thornton, P. K., Ericksen, P. J., Herrero, M., \& Challinor, A. J. 2014. Climate variability and vulnerability to climate change: a review. Global change biology, 20(11), 3313-3328.

TradingEconomics and Ghana Statistical Service 2017. Ghana Gross Domestic Product from Transport 2006-2017. Available at: https://tradingeconomics.com/ghana/gdp-from-transport

Transportation Research Board (TRB) 2008. Potential Impacts of Climate Change on US Transportation: Special report 290. Washington DC, National Academic Press. https://doi. org/10.17226/12179

UNDP-Africa Adaptation Programme (UNDP-AAP) 2011. Scoping and impact assessment review study for an integrated approach to broadening climate change adaptation into sectoral development: Transport infrastructure. Available at: https://www.undpaap.org/sites/undpaap.org/files/Ghana Report\%200n\%20Scoping\%20and\%20Impact\%20Assessment_Transport_2011.pdf

World Bank, 2010. Ghana: The economics of adaptation to climate change. Available: https://openknowledge.worldbank. org/bitstream/handle/10986/13212/762420V10ESW0P00Bo $\mathrm{x} 374367 \mathrm{~B} 00 \mathrm{PUBLIC} 0$. pdf? sequence $=1 \&$ isAllowed $=\mathrm{y}$ 